\title{
Effect of growth stages and fertility levels on growth, yield and quality of fodder oats (Avena sativa $L$.)
}

\author{
Gurjeet Kaur $^{1^{*}}$ and Meenakshi Goyal ${ }^{2}$ \\ ${ }^{1}$ Department of Biochemistry, Punjab Agricultural University, Ludhiana 141004 (Punjab), INDIA \\ ${ }^{2}$ Department of Plant Breeding and Genetics, Punjab Agricultural University, Ludhiana 141004 (Punjab), INDIA \\ *Corresponding author. E-mail: sidhugurjeet15@gmail.com
}

Received: May 9, 2016; Revised received: March 25, 2017; Accepted: June 6, 2017

\begin{abstract}
A field experiment was conducted to evaluate the yield and quality parameters of oats (Avena sativa L.) at forage research farm in Punjab Agricultural University, Ludhiana. Four different nitrogen levels viz. 0 (control), 50, 75 (recommended) and $100 \mathrm{Kg} \mathrm{N} /$ hawere applied in the form of urea. Samples were collected at three different growth stages i.e. 30, 45 and 60 DAS. As the growth of plant continued decrease in total nitrogen (45\%), non protein nitrogen $(37 \%)$, ether extract $(13 \%)$, ash content $(24 \%)$ and digestibility $(23 \%)$ was observed. But increase in free amino acids $(48 \%)$ and cell wall constituents i.e. ADF $(19 \%)$, NDF $(31 \%)$ and CF $(34 \%)$ with plant's growth was reported. The interactive effect of varying levels of inorganic fertilizer application on the chemical composition of the plant at various growth stages revealed an increase in total nitrogen (18\%), non protein nitrogen (26\%), ether extract (18\%), free amino acids (32\%), ash content (13\%) and digestibility $(7 \%)$ with increase in fertilizer level however ADF (7\%), NDF $(2 \%)$ and CF $(3 \%)$ content decreased with increased levels of nitrogen fertilization.Correlation studies showed that significant negative correlation was present forin vitro dry matter digestibility with acid detergent fiber $\left(r=-.861^{* *}\right)$, neutral detergent fiber $\left(r=-.891^{* *}\right)$ and crude fiber $\left(r=-.740^{* *}\right)$ at recommended dose of $\mathrm{N}$ fertilization. The objective of this study was to investigate the effect of different doses of nitrogen fertilization at different growth stages on quality components in oats fodder.
\end{abstract}

Keywords: Chemical composition, Growth stages, Nitrogen levels, Oats, Yield

\section{INTRODUCTION}

In agriculture the significance of fodder crops needs no emphasis due to the fact that livestock needs nutritious and regular fodder availability to meet the demand of milk, meat, butter and other by- products as per human demands (Devi, 2002). Among the different rabi fodder crops, oats (Avena sativa L.) is one of the most important rabi fodder crop. Oats requires the cool and moist weather for germination, tillering, booting and heading stage.It was produced in 10212 million ha area with an annual production of 233 million tons in the world. In India, cultivated fodder is limited to $4.9 \%$ of the total cropped area (Kumar et al., 2012). The total area under cultivated fodders is 8.6 million ha on individual crop basis. The crop occupies maximum area in Uttar Pradesh (34\%), followed by Punjab (20\%), Bihar (16\%), Haryana (9\%) and Madhya Pradesh (6\%).

Oats rank fifth in terms of world cereal production. It is extensively grown as forage crops and becoming increasingly importance in many regions of the world. It is the most important winter cereal fodder which is highly palatable, rich source of energy, protein, vitamin B1, phosphorus, iron and other minerals. Amongst various practices, cutting management and nutritional demands are important considerations to make the fod- der available to livestock especially during long lean period of winter. Fodder quality is of great importance as well as higher forage yield. The fodder quality of oats depends on many factors such as fertilization, irrigation, genotype, plant density and harvesting time. Maturity stage at harvest is the most important factor determining forage quality, and forage quality decreases with advancing maturity. Also, the maturity of forage crops influence forage digestibility and consumption by animals (Ball et al., 2001).

The most common variations associated with harvesting time are forage yield (Gul et al., 2008; Ayub et al., 2003), dry matter \% age, neutral and acid detergent fibre, CP (Khan et al., 2007) and in-vitro dry matter digestibility (Bayble et al., 1995). A high percentage of protein is required in the diet of ruminants because production of milk, meat and reproduction mainly depends on protein ingredient of the animals' diet (Arshadullah et al., 2011). The previous studies reflected that the quality of forages can be regulated by just selecting the harvest time at which plants are rich in nutrients concentration. Generally, fiber concentration of the forage crops increases while quality and digestibility decreases as aging prolongs (Ball et al., 2001). Forage digestibility is related to chemical compositions particularly of fiber, lignin and to some ex- 
tent of crude protein. Acid detergent fiber (ADF), and neutral detergent fiber (NDF) are commonly used as standard forage testing techniques for fiber analysis. $\mathrm{ADF}$ can be used to calculate digestibility, while intake potential is predicted through NDF (Ball et al., 2001). Crude fiber (CF) mainly consists of cellulose, hemicelluloses and lignin.

Nitrogen $(\mathrm{N})$ is major limiting nutrient for growth of forage crops and this explains the improvement in forage yield by external supply of $\mathrm{N}$ to soils that are deficient. (Tena and Beyene 2011). In most forage crops, the nitrogen fertilization resulted higher dry matter production (Ayubet al., 2007; Karasu et al., 2009), with higher protein (Keskin et al., 2005). While limited supply of nitrogen keeps the crops greenish for longer time (Russel et al., 1992) and reduces synthesis of organic nitrogen (Karic et al., 2005) in plants. Therefore, judicious rates of nitrogen application must be ensured for obtaining higher dry matter with good quality.

\section{MATERIALS AND METHODS}

Four oats genotypes OL-9, Kent, OL-10 and OL-125 were raised in experimental area of Department of Plant Breeding and Genetics PAU, Ludhiana $\left(30.9^{\circ} \mathrm{N}\right.$, $75.85^{\circ} \mathrm{E}$ and $252 \mathrm{~m}$ asl), India. The crop was sown on 12 November, 2014 in plots consisting of 15 rows with $20 \mathrm{~cm}$ spacing. The experiment was conducted in randomized block design (RBD) in factorial arrangement with three replications. For each genotype, four nitrogen treatments $(0,50,75$ (recommended dose), $100 \mathrm{Kg}$ $\mathrm{N} /$ ha) were given. Nitrogen was applied through urea in split doses as per the treatments. Half dose of $\mathrm{N}$ was applied at the time of irrigation and the remaining half was applied after one week of previous application. Whole plant samples were collected at three different growth stages i.e. 30,45 and 60 DAS to determine quality components. Yield and growth attributes were determined after 60 DAS. Fresh plant leaf samples were collected after every harvest, sun dried and then completely dried in hot air oven till a constant weight was obtained. This dried plant material was ground using Willy grinder to a uniform mesh size. The standard methods were used for neutral detergent fiber and acid detergent fiber (Georing and Van Soest, 1970), in vitro dry matter digestibility (Tilley and Terry, 1963), ether extract, ash, crude fiber, crude protein and non protein nitrogen (AOAC 1970) and Free amino acids (Lea and Takahashi, 1966). Data was statistically analyzed using analysis of variance (ANOVA). Further, mean separation of treatment effects was accomplished using Tukey's least significant difference test. All data analysis was carried out using SAS software.

\section{RESULTS AND DISCUSSION}

Chemical composition of oats fodder at different growth stages and $\mathbf{N}$ treatments: Total nitrogen con- tent decreased significantly $(\mathrm{F}=13968.22, \mathrm{p}<0.001)$ as the growth of plant continued (Table 1). At 60 DAS, maximum total nitrogen content was observed in OL125 genotype $(2.80 \%)$. Total nitrogen content generally decreased with the advancement of the plant growth due to the synthesis of structural carbohydrates with advancing plant age. Similar results were observed in wild soyabean (Zhai et al., 2008). $\mathrm{N}$ treatment resulted in significant $(\mathrm{F}=1376.05, \mathrm{p}<0.001)$ increase in total nitrogen content. Similar results were reported in fodder oats (Kumariet al.,2014), maize varieties (Tajulet al., 2013) and lettuce (Liu et al., 2014). This may be due to increased availability of nitrogen there by more uptake and corresponding increase in protein content of herbage. Maximum total nitrogen content in all genotypes was observed at $100 \mathrm{Kg} \mathrm{N} / \mathrm{ha}$ and minimum at $0 \mathrm{Kg} \mathrm{N} /$ ha.Non protein nitrogen $(\mathrm{NPN})$ content decreased significantly $(\mathrm{F}=3227.27, \mathrm{p}<0.001)$ as the growth of plant continued. Maximum NPN content was observed at 30 DAS. Nitrogen fertilization increased significantly $(\mathrm{F}=559.10, \mathrm{p}<0.001)$ NPN content. Maximum NPN content was observed at $100 \mathrm{Kg}$ $\mathrm{N} /$ ha in all genotypes at different growth stages. Eppendorfer (1971) reported that non-protein nitrogen is stored in the vegetative tissue at the expense of protein $\mathrm{N}$. Among different genotypes, maximum NPN content was observed in OL-10 (2.10\%) genotype.

In vitro dry matter digestibility (IVDMD) content decreased significantly with plant's growth $(F=2297.75$, $\mathrm{p}<0.001)$ as shown in Table 1 . Among growth stages, overall mean was observed maximum at 30 DAS $(88.39 \%)$ followed by 45 DAS $(82.61 \%)$ and 30 DAS $(67.67 \%)$. This may be due to the fact that in mature plants, stem comprise a much larger portion of the plant than leaves (Mcdonald et al., 2001). Similar results were observed in Panicum maximum (Taute et $a l ., 2002)$. Moderate levels of NDF and ADF at early growth stages may be responsible for generally high IVDMD in fodders (Njidda, 2014). Increasing $\mathrm{N}$ levels significantly $(\mathrm{F}=116.77, \mathrm{p}<0.001)$ increased the IVDMD content in fodder oats. Pathan et al. (2012) also reported similar findings in Napier bajra hybrid. Maximum digestibility at different $\mathrm{N}$ levels was observed in Kent genotype.

Acid detergent fiber (ADF) content increased significantly $(F=899.20, p<0.001)$ as the growth of plant continued and maximum ADF content in all genotypes was observed at 60 DAS (Table 2). Similar results were reported in maize (Firdous and Gilani 1998) and sorghum (Firdous and Gilani 2001). The significant $(\mathrm{F}=649.75, \mathrm{p}<0.001)$ decrease in ADF content was observed with $\mathrm{N}$ fertilization in fodder oats. This may be due to the fact that increased uptake of nitrogen imparts succulence to green plants by reducing fiber content. Similar results have been reported for fodder oats (Kumari et al., 2014), Brassica rapa L. (Paul et al., 2014), Napier bajra hybrid (Sharma et al., 2012) 
Gurjeet Kaur and Meenakshi Goyal / J. Appl. \& Nat. Sci. 9 (3): 1287 -1296 (2017)
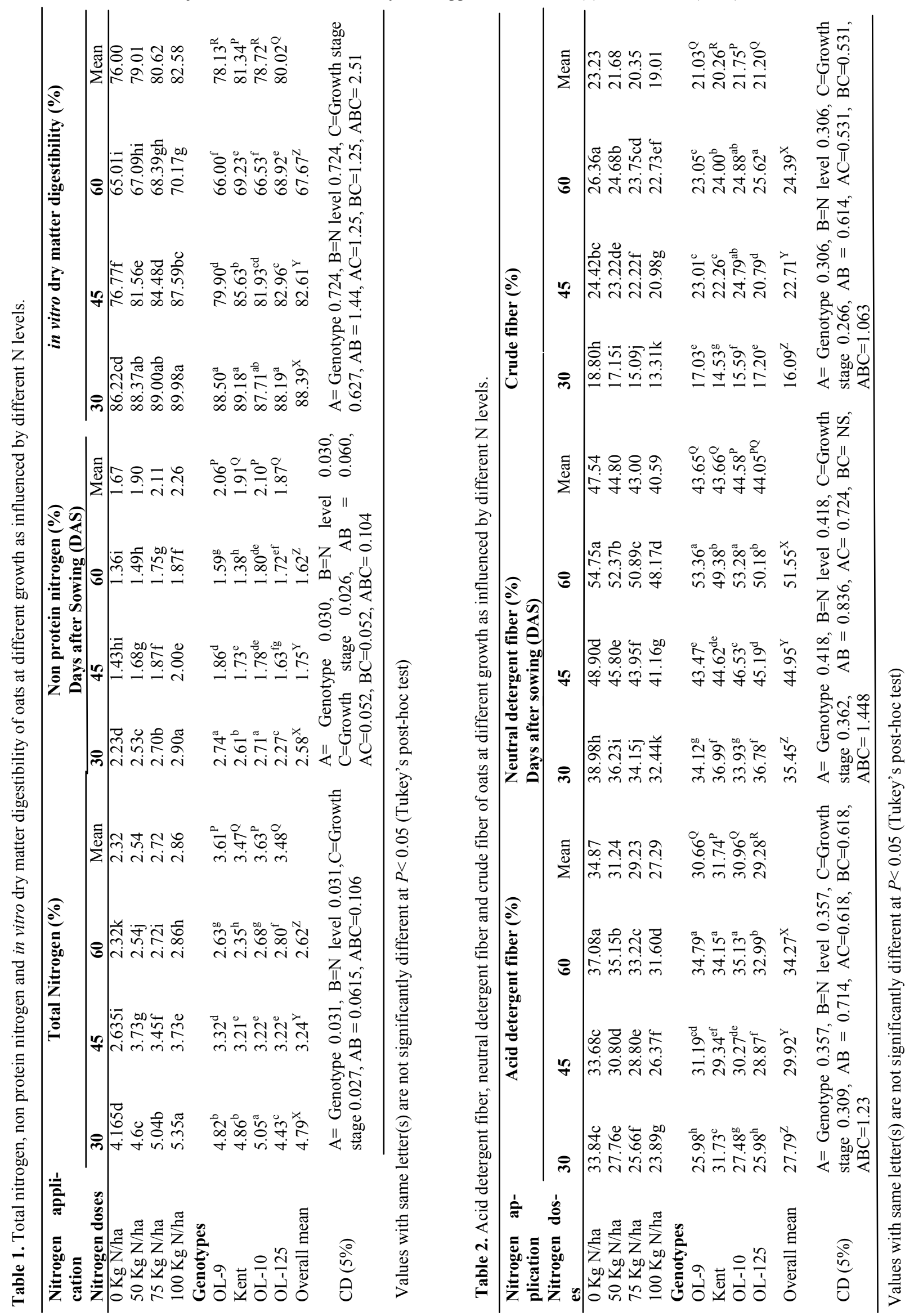


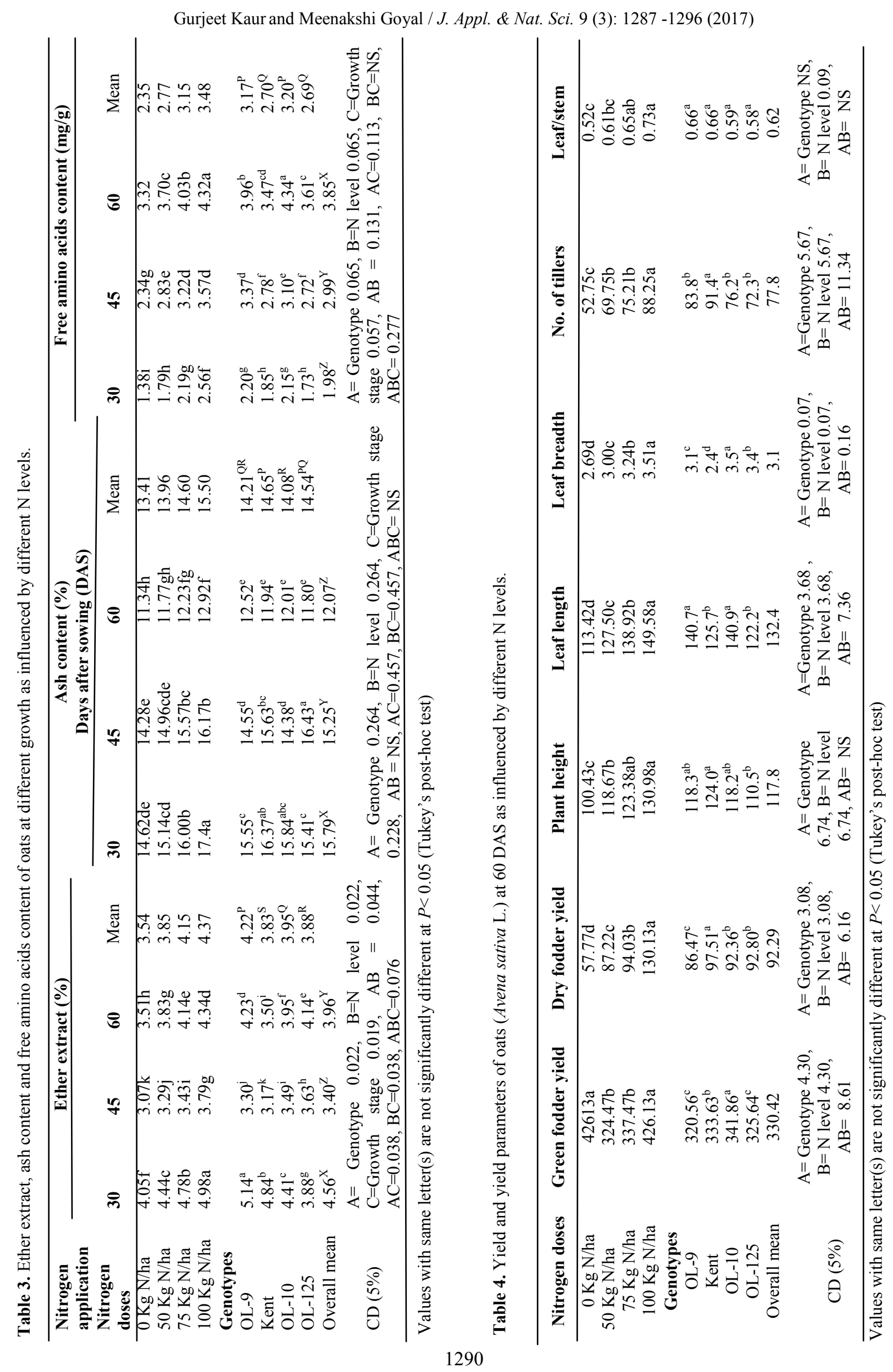


Gurjeet Kaur and Meenakshi Goyal / J. Appl. \& Nat. Sci. 9 (3): 1287 -1296 (2017)

Table 5. Correlation coefficient between quality components of oats at different growth stages.

\begin{tabular}{|c|c|c|c|c|c|c|c|c|c|}
\hline $\begin{array}{c}\text { Quality } \\
\text { components }\end{array}$ & DAS & $\begin{array}{l}\text { Total } \\
\text { Nitrogen }\end{array}$ & $\begin{array}{l}\text { Non } \\
\text { protein } \\
\text { nitrogen }\end{array}$ & $\begin{array}{l}\text { Ether } \\
\text { extract }\end{array}$ & Ash & $\begin{array}{l}\text { Free } \\
\text { amino } \\
\text { acids }\end{array}$ & $\begin{array}{l}\text { In vitro } \\
\text { dry mat- } \\
\text { ter di- } \\
\text { gestibilit } \\
y\end{array}$ & $\begin{array}{l}\text { Acid } \\
\text { deter- } \\
\text { gent } \\
\text { fibre }\end{array}$ & $\begin{array}{l}\text { Neutral } \\
\text { deter- } \\
\text { gent } \\
\text { fibre }\end{array}$ \\
\hline \multirow{3}{*}{$\begin{array}{l}\text { Non protein } \\
\text { nitrogen }\end{array}$} & 30 & $.906^{* *}$ & & & & & & & \\
\hline & 45 & $.934 * *$ & & & & & & & \\
\hline & 60 & $.892 * *$ & & & & & & & \\
\hline \multirow{3}{*}{ Ether extract } & 30 & $.662 * *$ & $.777 * *$ & & & & & & \\
\hline & 45 & $.701 * *$ & $.576^{*}$ & & & & & & \\
\hline & 60 & $.849 * *$ & $.816^{* *}$ & & & & & & \\
\hline \multirow{3}{*}{ Ash } & 30 & $.805^{* *}$ & $.744 * *$ & $.603^{*}$ & & & & & \\
\hline & 45 & $.561 *$ & .330 & $.540^{*}$ & & & & & \\
\hline & 60 & $.538 *$ & $.606^{*}$ & $.728 * *$ & & & & & \\
\hline \multirow{3}{*}{$\begin{array}{l}\text { Free amino } \\
\text { acids }\end{array}$} & 30 & $.792 * *$ & $.831 * *$ & $.706 * *$ & $.770 * *$ & & & & \\
\hline & 45 & $.872 * *$ & $.970 * *$ & $.591^{*}$ & .215 & & & & \\
\hline & 60 & $.731^{* *}$ & $.835 * *$ & $.712 * *$ & $.693 * *$ & & & & \\
\hline \multirow{3}{*}{$\begin{array}{l}\text { In vitro dry } \\
\text { matter digesti- } \\
\text { bility }\end{array}$} & 30 & $.662 * *$ & $.638 * *$ & $.615^{*}$ & $.719 * *$ & $.679 * *$ & & & \\
\hline & 45 & $.700 * *$ & $.640 * *$ & $.571 *$ & $.661 * *$ & $.533 *$ & & & \\
\hline & 60 & .496 & .413 & .286 & .381 & .217 & & & \\
\hline \multirow{3}{*}{$\begin{array}{l}\text { Acid detergent } \\
\text { fibre }\end{array}$} & 30 & $-.594 *$ & $-.550 *$ & -.369 & -.480 & $-.751 * *$ & $-.607 *$ & & \\
\hline & 45 & $-.795^{* *}$ & $-.682 * *$ & $-.774 * *$ & $-.707 * *$ & $-.601 *$ & $-.900 * *$ & & \\
\hline & 60 & $-.740 * *$ & $-.662 * *$ & $-.656^{* *}$ & $-.628 * *$ & $-.500 *$ & $-.884 * *$ & & \\
\hline \multirow{4}{*}{$\begin{array}{l}\text { Neutral deter- } \\
\text { gent fibre }\end{array}$} & 30 & $-.886 * *$ & $-.879 * *$ & $-.636^{* *}$ & $-.697 * *$ & $-.906^{* *}$ & $-.609 *$ & $.809 * *$ & \\
\hline & 45 & $-.936 * *$ & $-.902 * *$ & $-.599 *$ & $-.569 *$ & $-.849 * *$ & $-.659 * *$ & $.730 * *$ & \\
\hline & 60 & -.455 & -.383 & -.308 & $-.500 *$ & -.204 & $-.934 * *$ & $.833 * *$ & \\
\hline & 30 & $-.610 *$ & -.456 & -.129 & $-.750 * *$ & $-.581 *$ & $-.606^{*}$ & .460 & $.518^{*}$ \\
\hline \multirow[t]{2}{*}{ Crude fibre } & 45 & $-.860 * *$ & $-.800 * *$ & $-.751 * *$ & $-.668^{* *}$ & $-.723 * *$ & $-.857 * *$ & $.887 * *$ & $.801 * *$ \\
\hline & 60 & $-.752 * *$ & $-.679 * *$ & $-.724 * *$ & $-.746^{* *}$ & $-.700 * *$ & $-.657 * *$ & $.817 * *$ & $.620 *$ \\
\hline
\end{tabular}

** - Significant at p 0.01, * - Significant at p 0.05

Table 6. Correlation coefficient between quality components of oats at recommended ( $75 \mathrm{Kg} \mathrm{N} / \mathrm{ha}$ ) nitrogen dose.

\begin{tabular}{|c|c|c|c|c|c|c|c|c|}
\hline & $\begin{array}{l}\text { Total } \mathrm{Ni}- \\
\text { trogen }\end{array}$ & $\begin{array}{l}\text { Non pro- } \\
\text { tein nitro- } \\
\text { gen }\end{array}$ & $\begin{array}{l}\text { Ether } \\
\text { extract }\end{array}$ & Ash & $\begin{array}{l}\text { Free ami- } \\
\text { no acids }\end{array}$ & $\begin{array}{l}\text { In vitro } \\
\text { dry mat- } \\
\text { ter digesti- } \\
\text { bility } \\
\end{array}$ & $\begin{array}{l}\text { Acid de- } \\
\text { tergent } \\
\text { fibre }\end{array}$ & $\begin{array}{l}\text { Neutral } \\
\text { detergent } \\
\text { fibre }\end{array}$ \\
\hline $\begin{array}{l}\text { Non protein } \\
\text { nitrogen }\end{array}$ & $.924 * *$ & & & & & & & \\
\hline Ether extract & $.587 *$ & $.767^{* *}$ & & & & & & \\
\hline Ash & $.725^{* *}$ & .551 & .127 & & & & & \\
\hline $\begin{array}{l}\text { Free amino } \\
\text { acids }\end{array}$ & $.835^{* *}$ & $.661^{*}$ & .140 & $.903 * *$ & $-.890 * *$ & & & \\
\hline $\begin{array}{l}\text { Acid deter- } \\
\text { gent fibre }\end{array}$ & $-.855^{* *}$ & $-.679 * *$ & -.225 & $-.707 *$ & $.886^{* *}$ & $-.861 * *$ & & \\
\hline $\begin{array}{l}\text { Neutral deter- } \\
\text { gent fibre }\end{array}$ & $-.968 * *$ & $-.837 * *$ & -.447 & $-.768^{* *}$ & $.922 * *$ & $-.891 * *$ & $.890 * *$ & \\
\hline Crude fibre & $-.917 * *$ & $-.852 * *$ & $-.690 *$ & $-.716^{* *}$ & $.871 * *$ & $-.740 * *$ & $.686^{*}$ & $.909 * *$ \\
\hline
\end{tabular}

** - Significant at p $0.01, *$ - Significant at p 0.05

and Bermuda grass (Kering et al., 2011). From high yielding mal feeding point of view, fodder with low ADF as well as NDF is always preferred.

The content of Neutral detergent fiber (NDF) increased significantly $(\mathrm{F}=3946.48, \mathrm{p}<0.001)$ with growth of plant (Table 2). On average at each growth stage, maximum content was observed at 60 DAS $(51.55 \%)$. Fird- ous and Gilani (2001) also observed increased NDF content with plant's growth in sorghum species. $\mathrm{N}$ fertilization resulted in significant $(F=389, p<0.001)$ decrease in NDF content in fodder oats. On average, minimum NDF content was observed in OL-9 genotype $(43.65 \%)$. Patel et al. (2007) reported that increased supply of $\mathrm{N}$ fertilization and other minerals 
resulted in decreased levels of NDF content in fodder maize. Balabanli et al. (2010) also reported that NDF content peaked at low fertilizer levels and then decreased with increasing fertilizer rates.

Crude fiber (CF) mainly consists of cellulose, hemicelluloses and lignin. CF content above $30-35 \%$ is usually considered undesirable component in forages (Table 2). $\mathrm{CF}$ content increased significantly $(\mathrm{F}=2152.67$, $\mathrm{p}<0.001$ ) with growth of plant and was found maximum at 60 DAS $(24.39 \%)$ and minimum at 30 DAS $(16.09 \%)$. Similar results were observed in oats (Xiangfeng et al., 2007). Higher doses of $\mathrm{N}$ fertilization resulted in significant $(\mathrm{F}=8.27, \mathrm{p}<0.001)$ decrease in the CF content. This might be due to the fact that nitrogen application increased the uptake of nitrogen which is the constituent of amino acids and protein and decreased the pectin, cellulose and hemicellulose content which are major constituents of fibre (Babu et al., 1995). Maximum CF content in all genotypes was observed at control conditions ( $0 \mathrm{Kg} \mathrm{N} / \mathrm{ha})$. Among different $\mathrm{N}$ fertilization rates, mean values showed minimum CF content in Kent genotype (20.26 \%). Similar results were reported in oats (Iqbal et al., 2013), fodder sorghum (Singh and Sumeriya, 2012), pearl millet (Rostamza et al., 2011) and cowpea (Hasan et al., 2010). The fodder having less crude fiber percentage is considered a good quality because higher the crude fiber percentage lesser will be digestibility. Therefore, because the application of nitrogen decreased fiber content, so it increased digestibility of the plants. Significant differences were depicted in crude fiber among genotypes and maximum CF content was observed in OL-10 genotype (21.75\%).

Ether extract (EE) is composed of fats, oils, waxes, organic acids, pigments, sterols and vitamins A, D, E and K.Ether extractcontent varied significantly among different growth stages $(\mathrm{F}=7446.57, \mathrm{p}<0.05)$. At 30 and 60 DAS maximum EE content in OL-9 genotype (5.14 \% and $4.23 \%$ resp.) and at 45 DAS in OL-125 genotype (3.63\%) was observed (Table 3). Increasing $\mathrm{N}$ levels, increased $\mathrm{EE}$ content significantly $(\mathrm{F}=$ 2055.74, $\mathrm{p}<0.001$ ) at different growth stages of fodder oats. Earlier investigation by Uddin et al., (2005) who reported that EE content of oat forage increased significantly $(\mathrm{P}<0.01)$ with the increasing level of $\mathrm{N}$ fertilizer from 0 to $115 \mathrm{~kg} \mathrm{~N} / \mathrm{ha}$. Similar trend of EE content with increasing dose of $\mathrm{N}$ fertilization was observed in fodder oats (Kumari et al., 2014 ;Vuckovic et al., 2005) and fodder pearl millet (Meena et al., 2012).

Ash content was observed maximum at early growth stages of oats fodder (Table 3 ) and decreased significantly with plant's growth $(F=610.75, p<0.05)$. Similar results were observed in baby corn that mineral content was observed higher at early growth stages as compared to later growth stages (Thavaprakaash et al., 2008). N application significantly increased total ash content $(\mathrm{F}=90.31, \mathrm{p}<0.001)$. Increase in ash content with increasing dose of $\mathrm{N}$ fertilization may be due to the increased availability of $\mathrm{N}$ to the plants and mineral matter. Ruso (2006) explained that rates of nitrogen inputs are to maximize the level of nutrients in plants.Similar results were observed in fodder oats (Kumari et al., 2014 and Mahale et al., 2003), mustard (Paul et al., 2014) and fodder sorghum (Ayubet al., 2002). The data presenting the ash contents showed that oats genotypes exhibited significant $(\mathrm{F}=8.36$, $\mathrm{p}<0.05)$ variations for ash contents. Mean values showed maximum ash content in Kent genotype $(14.65 \%)$ and minimum in OL-10 genotype (14.08\%). The significant variations in ash contents among oats genotypes have already been confirmed (Khan et al.,2014). This may be due to differences in nutrient absorption from soil and utilization within the plants by different genotypes.

Free amino acid content was observed maximum at 60 DAS $(3.85 \mathrm{mg} / \mathrm{g})$ followed by 45 DAS $(2.99 \mathrm{mg} / \mathrm{g})$ and 30 DAS $(1.98 \mathrm{mg} / \mathrm{g}) \quad(\mathrm{F}=2128.87, \mathrm{p}<0.001)$ (Table 3). Roy et al. (2013) observed highest amino acid content in mature leaves followed by young and senescent leaves in sunflower. Treatment with nitrogen fertilization resulted in significant increase in free amino acids content $(\mathrm{F}=439.18, \mathrm{p}<0.001)$. Similar results were observed in wheat (Kaur et al., 2015) and maize (Losak et al., 2010) crop.

Yield: GFY increased significantly $(\mathrm{F}=2781.08$, $\mathrm{p}<0.001)$ with $\mathrm{N}$ fertilization. Khogali et al., (2011) observed increasing trend of GFY with $\mathrm{N}$ fertilization in fodder oats. Similar results were observed by some other researchers in maize (Paschalidis X et al., 2015 and Sharma et al., 2016), oats (Kumari et al., 2014), pearl millet (Shahin et al.,2013 and Ayub et al., 2007) and napierbajra hybrid (Tiwanaet al., 2004). The yield of an agricultural crop strongly dependent on the supply of mineral nutrients, particularly N (Sawan, 2006). Among genotypes, mean values showed maximum GFY content in OL-10 (341.86 q/ha) and minimum in OL-9 (320.56 q/ha). Genotypic differences were also observed in pearl millet (Damame et al., 2013) and fodder sorghum (Singh and Sumeriya, 2012). Significant interaction was observed between genotypes and $\mathrm{N}$ levels $(\mathrm{F}=67.74, \mathrm{p}<0.001)$.

Dry fodder yield (DFY) increased significantly $(\mathrm{F}=775.9, \mathrm{p}<0.001)$ with $\mathrm{N}$ fertilization. Similar results were observed in fodder sorghum (Somashekaret al.,2014 ; Damame et al., 2013), Brassica rapa L (Paul et al.,2014), and fodder maize (Gasim, 2001). In a study, DM yield of some tropical grasses had peaked at $\mathrm{N}$ application of $300 \mathrm{Kg} / \mathrm{ha}$ (Rahman et al., 2008). Among genotypes, mean values showed maximum DFY in Kent $(97.51 \mathrm{q} / \mathrm{ha})$ and minimum in OL-9 (86.47 q/ha). Genotypic differences were also observed in pearl millet (Damame et al., 2013) and fodder sorghum (Dixit et al., 2005). Significant interaction $(F=7.14, p<0.001)$ between genotypes and $\mathrm{N}$ lev- 
els were observed.

Growth attributes: Plant height increased significantly $(\mathrm{F}=30.96, \mathrm{p}<0.001)$ with $\mathrm{N}$ fertilization. Maximum plant height was observed at $100 \mathrm{Kg} \mathrm{N} / \mathrm{ha}$. An increase in plant height with $\mathrm{N}$ fertilization was observed in maize (PaschalidisX et al.,2015 and Sharma et al., 2016), oats (Dawit and Wegi 2014) and rice (Mizanet al.,2010). Several other researchers also found positive relation of $\mathrm{N}$ fertilization with plant height (Dubey et al.2013, Shahin et al.,2013, Oadet al.,2004 and Gasim, 2001). Genotypes varied significantly ( $F=7.86$, $\mathrm{p}<0.01)$ in terms of plant height. Among genotypes mean values showed maximum plant height in Kent $(124 \mathrm{~cm})$.

Leaf length increased significantly $(\mathrm{F}=147.93$, $\mathrm{p}<0.001)$ with $\mathrm{N}$ fertilization. Similar results of increasing leaf length with $\mathrm{N}$ fertilization were reported in fodder maize varieties (Amin and Hasan, 2011). An increased leaf area index with $\mathrm{N}$ fertilization was observed in oats varieties (Dubey et al.,2013) and in chickpea (Namvaret al.,2011). Among genotypes, mean values showed maximum leaf length in OL-10 $(140.9 \mathrm{~cm})$ and minimum in OL-125 $(122.2 \mathrm{~cm})$. Similar results were observed in oats varieties (Dubey et al.,2013).

Leaf breadth increased significantly $(\mathrm{F}=158.24$, $\mathrm{p}<0.001)$ with $\mathrm{N}$ fertilization. An increase in leaf area index with $\mathrm{N}$ fertilization was observed in maize (Tajul et al., 2013, Amin and Hasan, 2011, Aslam et al., 2011 ;Onasanya et al., 2009), wheat (Kibe et al., 2006), soyabean (Malik et al., 2006), barley (Alam and Haider, 2006) and mottgrass (Zahid et al., 2002). Among genotypes, mean values showed maximum leaf breadth in OL-10 $(3.5 \mathrm{~cm})$ and minimum in Kent $(2.4$ $\mathrm{cm})$.

No. of tillers increased significantly $(\mathrm{F}=56.03$, $\mathrm{p}<0.001)$ with nitrogen fertilization. Similar results were obtained in oats fodder by several researchers (Ahmad et al., 2011, Hasan and Shah, 2000). The number of tillers increased with increase in $\mathrm{N}$ fertilization in the second growth of crop in Ruzi grass (Batista et al., 2014). Among genotypes, maximum no. of tillers was observed in Kent (91.4). Significant interaction $(\mathrm{F}=3.04, \mathrm{p}>0.01)$ between genotypes and $\mathrm{N}$ levels.

Leaf/stem ratio is an important component of forage quality. It varied non- significantly $(\mathrm{F}=7.80, \mathrm{p}<0.05)$ with $\mathrm{N}$ fertilization. An increase in L/S with $\mathrm{N}$ application upto $80 \mathrm{Kg} \mathrm{N} /$ ha and then decrease at $120 \mathrm{~kg} \mathrm{~N} / \mathrm{ha}$ in fodder oats (Luikhamet al., 2012). Similar results were reported in oats (Dawit and Wegi, 2014) and fodder maize (Sharma et al., 2016 and Gasim, 2001). Among genotypes, mean values showed maximum leaf/stem was in OL-9 (0.66) and Kent (0.66). Nonsignificant $(\mathrm{F}=0.31, \mathrm{p}>0.05)$ interaction was observed between genotype and $\mathrm{N}$ level.

Correlation studies: At recommended dose of nitrogen fertilization ( $75 \mathrm{Kg} \mathrm{N} / \mathrm{ha}$ ) significant positive cor- relation was observed between total nitrogen, non protein nitrogen, ash and in vitro dry matter digestibility (Table 5). However, negative correlation was observed $\mathrm{N}$ levels with acid detergent fiber, neutral detergent fiber and crude fiber (Table 6). At different growth stages significant negative correlation was observed between ADF, NDF and CF content.

\section{Conclusion}

From present study it can be concluded that nitrogen doses and growth stages significantly affect the quality of fodder oats. As the growth of plant continued; non protein nitrogen, total nitrogen and ether content decreased significantly but ADF, NDF and CF increased affecting the digestibility of crop. With increased dose of $\mathrm{N}$ application cell wall constituents i.e. ADF, NDF and CF decreased significantly.

\section{REFERENCES}

Ahmad, A. H., Tariq, M., Ayub, M., Elahi, M., Chaudhary, M. N. and Nadeem, M. A. (2011). Forage yield and some quality attributes of mille (Pennisetuma merican$u m \mathrm{~L}$.) hybrid under various regimes of nitrogen fertilization and harvesting dates. African Journal of Agricultural Reserach, 6(16): 3883-90.

Alam, M. Z. and Haider, S. A. (2006). Growth attributes of barley (Hordeum Vulgare L.) cultivars in relation to different doses of nitrogen fertilizer. Journal of Life and Earth Science, 1(2): 77-82.

Amin, M. and Hasan, E. M.,(2011). Effect of different nitrogen sources on growth, yield and quality of fodder maize (Zea mays L.). Journal of Saudi Society of Agricultural Sciences, 10: 17-23.

AOAC (1970). official Methods of Analysis (11 ${ }^{\text {th }}$ ed.) Association of official analytical chemists, Washington, D.C.

Arshadullah, M., Malik, M. A., Rasheed, M., Jilani, G., Zahoor, F. and Kaleem, S. (2011). Seasonal and Genotypic Variations Influence the Biomass and Nutritional Ingredients of Cenchrusciliaris Grass Forage. International Journal Of Agriculture \& Biology, 13:120-124.

Aslam, M., Iqbal, S., Zamir, M. S. I., Mubeen, M. and Amin, M. (2011). Effect of different nitrogen levels and seed rates on yield and quality of maize fodder. Crop \& Environment, 2(2): 47-51.

Ayub, M., Nadeem, M. A. andSuleheri, M. J. (2003). Effect of harvesting times on maize fodder yield and quality. Bangladesh Journal of Agriculture, 27: (28) 71-5.

Ayub, M., Nadeem, M. A., Tanveer, A. and Husnain, A. (2002). Effect of different levels of nitrogen and harvesting times on growth, yield and quality of sorghum fodder. Asian Journal of Plant Sciences, 4: 304-7.

Ayub, M., Nadeem, M. A, Tanvir, A, Tahir, M., Khan, R. M. A. 2007. Interactive effect of different nitrogen levels and seeding rates on fodder yield and quality of pearl millet. Pakistan Journal of Agricultural Science, 44: 592-6.

Babu, R., Gumaste, S., Patil, T.C. and Prabhakar, A.S. (1995). Effect of stage of cutting, nitrogen and phosphorus levels on forage pearl millet [Pennisetum glaucum (L.)]. Forage research,20(4): 225-31.

Balabanli, C., Albayrak, S. and Yüksel, O. (2010). Effects of 
nitrogen, phosphorus and potassium fertilization on the quality and yield of native rangeland. Turkish Journal of Field Crops, 15(2): 164-8.

Ball, D. M., Collins, M., Lacefield, G. D., Martin, N. P., Mertens, D. A., Olson, K. A., Putnam D. H., Undersander, D. J. and Wolf, M. W. (2001). Understanding Forage Quality. American Farm Bureau Federation Publication 1-01, Park Ridge, Illinois, USA.

Batista, K., Giacomini, A. A., Gerdes, L., Mattos, W. T., Colloza, M. T. and Otsuk, I. P. (2014). Influence of Nitrogen on the production characteristics of ruzi grass. African Journal of Agricultural Research, 9(5):533-8.

Bayble, T., Melaku, S. and Prasad, N. K. (1995). Effects of cutting dates on nutritive value of Napier (Pennisetum purpureum) grass planted sole and in association with Desmodium (Desmodium intortum) or Lablab (Lablab purpureus). In: Proceedings of 3rd National Conference of the Ethiopian Society of Animal Production, Pp. 316322

Damame, S. V., Bhingarde, R. N. and Pathan, S. H. (2013). Effect of different nitrogen levels on nutritional quality and nitrate nitrogen accumulation in forage pearl millet genotypes grown under rainfed conditions. Forage Research, 39(2): 93-95

Dawit, A. and Wegi, T. (2014). Determination of optimum seed and fertilizer rate for fodder oat in Bale Highland South eastern Ethopia. International Journal of Soil and Crop Science, 2(7): 73-76

Devi, L. G. (2002). Forage yield of maize (Zea mays L.) as influenced by nitrogen levels and bio-fertilizers. Forage Research 27: 263-6

Dixit, A. K.., Kachroo, D. and Bali, A. S. (2005). Response of promising rainy season sorghum [Sorghum bicolor (L.) Moench] genotypes to nitrogen and phosphorus fertilization. Indian Journal of Agronomy, 50 : 206-9

Dubey, A., Rathi, G. S. and Sahu, R. (2013). Effect of nitrogen levels on green fodder yield of oat (Avena sativa) varieties. Forage Research, 39(1): 39-41

Eppendorfer, W. H. (1971). Effect of sulfur, nitrogen and phosphoruson the amino acid composition of the field bean (Viciafaba) and responses of the biological value of the seed protein and sulfur-amino acid content. Journal of Science and Food Agriculture, 22:501-5

Firdous, R. and Gilani, A. H. (1998). Effect of stage of growth and cultivator on chemical composition of whole maize plant and its morphological fractions. Asian-Australian Journal of Animal Sciences, 12(3): 366-370

Firdous, R. and Gilani, A H. (2001). Changes in chemical composition of sorghum as influenced by growth stage and cultivar Asian-Australian Journal of Animal Sciences, 7:935-40

Gasim, S. H. (2001). Effect of nitrogen, phosphorus and seed rate on growth, yield and quality of forage maize (Zea mays L.). M.Sc.Thesis, Faculty of Agric Univ of Khartoum.

Georing, H. K. and Van Soest, P. J. (1970). Forage fibre analysis, Apparatus reagents, procedures and some application. Agriculture hand book No. 379, USA Washington, D.C

Gul, I., Demirel, R., Kilicalp, N., Sumerli, M. and Kilc, H. (2008). Effect of crop maturity stages on yield, silage chemical composition and in-vivo digestibilities of maize, sorghum and sorghum-sudangrass hybrids grown in semi-arid conditions. Journal of Animal and Veterinary, 7: 1021-28.

Hasan, B. and Shah, W. A. (2000). Biomass grain production and quality of oat (Avena sativa) under different cutting regimes and nitrogen levels. Cereal Reserach Communication, 28:203-10.

Hasan, M. R., Akbar, M. A., Khandaker, Z. H. and Rahman, M. M. (2010). Effect of nitrogen fertilizer on yield contributing character, biomass yield and nutritive value of cowpea forage. Bangaldesh Journal of Animal Sciences, 39(1\&2): 83-88.

Iqbal, M. F., Iqbal, Z., Farooq, M., Ali, L. and Fiaz, M. (2013). Impact nitrogenous fertilizer on yield and quality of oat. Pakistan Journal of Science, 65(1): 1-4.

Karasu, A., Oz, M., Bayram, G., Turgut, I. (2009). The effect of nitrogen levels on forage yield and some attributes in some hybrid corn (Zeamaysindentata Sturt.) cultivars sown as second crop for silage. African Journal of Agricultural Research., 4:166-70.

Karic, L., Vukasinovic, S. and Znidarcic, D. (2005). Response of leek (Allium porrum L.) to different levels of nitrogen dose under agro-climate conditions of Bosnia and Herzegovina. Acta AgriculturaeSlovenica, 85: 2196.

Kaur, G., Asthir, B., Bains, N. S. and Farooq, M. (2015) Nitrogen nutrition, its assimilation and remobilization in diverse genotypes.International Journal of Agricultural Biology, 17:531-8.

Kering, Maru, K., Guretzky, J., Funderburg, E. and Mosali, J. (2011). Effect of nitrogen fertilizer rate and harvest season on forage yield, quality and macronutrient concentrations in midland bermuda grass. Communication in Soil Sciences and Plant Analysis Journal, 42:195871

Keskin, B., Akdeniz, H., Yilmaz, I. H., Turan, N. (2005). Yield and quality of forage corn (Zea mays L.) as influenced by cultivars and nitrogen rates.Jouranl of Agronomy, 4: 138-41.

Khan, A., Anjum, M. H., Rehman, M. K. U., Zaman, Q. and Ullah, R.(2014). Comparative Study on Quantitative and Qualitative Characters of Different Oat (Avena sativa L.) genotypes under Agro-Climatic conditions of Sargodha,Pakistan. American Journal of Plant Sciences, 5: 3097-103

Khan, H. K., Khan, A. G., Sarwar, M., Azim, A. (2007). Effect of maturity on production efficiency, nutritive value, and in-situ nutrient digestibility of three cereal fodders. International Journal of Agricultural Research, 2: 900-9.

Khogali,Muna, E., DagashYassin, M. I. and EL-Hag Mahgoub, G. (2011).Productivity of fodder beet (Beta vulgaris var. Crassa) cultivars affected by nitrogen and plant spacing. Agriculture and Biology Journal North America, 2(5): 791-98.

Kibe, A. M., Singh, S. and Karla, N. (2006). Water nitrogen relationship for wheat growth and productivity in late sown conditions. Agricultural water Management, 8(4): 221-28

Kumar, S., Agrawal, R. K., Dixit, A. K., Rai, A. K., Singh, J. B., Rai, S. K. (2012). Forage Production Technology for Arable Lands. Technology Bulletin No. 01/2012.

Kumari, A., Kumar, P., Ahmad, E., Singh, M., Kumar, R., Yadav, R. K., Datt, C. and Chinchmalatpure, A. (2014). Fodder yield and quality of oat fodder (Avena Sativa) as 
influenced by salinity of irrigation water and applied nitrogen levels. Indian Journal of Animal Nutrition, 31 (3): 266-71.

Lea, Y. P. and Takahashi, T. (1966). An improved colorimetric determination of amino acid with the use of ninhydrin. Analytical Biochemistry, 14: 71-77.

Liu, C. W., Sung, Y., Chen, B. C. and Lia, H. Y. (2014). Effects of nitrogen fertilizers on the growth and nitrate content of lettuce (Lactuca sativa L.). International Journal of Environmental Research and Public Health, 11:4427-40.

Losak, T., Vollmann, J., Hlusek, J., Peterka, J., Filipik, R. and Praskova, L.(2010). Influence of combined nitrogen and sulphur fertilization on false flax (Camelina sativa L. Crtz.) yield and quality. Acta Aliment, 39:431-44.

Luikham, E., Kamei, S. and Mariam, Anal, P. S.,(2012). Yield, quality and economics of oat fodder (Avena sati$v a$ L.) as influenced by nitrogen and varieties. Forage Research, 38(2): 112-4.

Mahale, B. B., Nevase, V. B., Thorat, S. T. and Dhekale, J. S. (2003). Effect of non-symbiotic nitrogen fixers on the forage yield of oat (Avena sativa L). Annals of Agriculture Research Indian Society of Agriculture Sciences, 24: 121-3.

Malik, M. A., Cheema, M. A., and Khan, H. Z. (2006). Growth and yield response of soybean (Glycine max L.) to seed inoculation and varying phosphorus levels. Journal of Agricultural Research, 44(1): 47-53.

McDonald, P., Edwards, R. A., Greenhalgh, J. F. D. and Morgan, C. A. (2001). Animal Nutrition (6th ed.). Prentice Hall, Essex. Pp. 495-514.

Meena, S. N., Jain, K. K., Prasad, D. and Ram, A. (2012). Effect of nitrogen on growth, yield and quality of fodder pearl millet (Pennisetum glaucum) cultivars under irrigated conditionof North-Western Rajasthan. Annals of Agriculture Research New Series, 33 (3) : 183-188

Mizan, R. (2010). Effect of nitrogen and plant spacing on the yield of Boro rice cv. BRRI dhan45. Pp. 32

Namvar, A., Sharifi, R. S. and Khandan, T. (2011). Growth analysis and yield of chickpea (Cicerarietinum L.) in relation to organic and inorganic nitrogen fertilization. Ekologija, 57(3): 97-108.

Njidda, A. A. (2014). Determining dry matter degradability of some semi-arid browse species of north- eastern $\mathrm{Ni}$ geria using the in vitro technique. Nigerian Journal of Basic and Applied Science, 18(2): 160-167.

Oad, F. C., Buriro, U. A. and Agha, S. K. (2004). Effect of organic and inorganic fertilizer application on maize fodder production. Asian Journal of Plant Sciences, 3:375-7.

Onasanya, R. O.,Aiyelari, O. P., Onasanya, A., Oikeh, S., Nwilene, F. E., and Oyelakin, O. O.,(2009). Growth and yield response of maize (Zea mays L.) to different rates of nitrogen and phosphorus fertilizers in southern Ngeria. World Journal of Agricultural Sciences, 5 (4): 4007.

Paschalidis, X., Ioannou, Z., Mouroutoglou, X., Koriki, A., Kavvadias, V., Baruchas, P., Chouliaras, I. and Sotiropoulos, S. (2015). Effect of Fertilization and Irrigation on Plant Mass Accumulation and Maize production (Zea mays). International Journal of Waste Resources, 5(1): 1000173.

Patel, A. S., Sadhu, A. C., Patel, M. R. and Patel, P. C. (2007) Effect of zinc, FYM and fertility levels on yield and quality of forage maize Forage Research,32(4): 209 -12 .

Pathan, S. H., Tumbare, A. D. and Kamble, A. B. (2012). Impact of planting material, cutting management and fertilizer levels on nutritional quality of bajra $\mathrm{x}$ napier hybrid. Forage Research,38(2): 74-79

Paul, K., Chopra, N. K., Soni, P. G., Kumar, R. and Mondal, G. (2014). Influence of Different Nitrogen Levels and Weed Control on Yield and Chemical Composition of Mustard (Brassica rapa L. sub. chinensis) Fodder. Indian Journal of Animal Nutrition, 31 (4): 400-3.

Rostamza, M., Mohammad-Reza, C., Mohammad-Reza, J. and Ahmad, A. (2011). Forage quality, water use and nitrogen utilization efficiencies of pearl millet (PennisetumamericanumL.) grown under different soil moisture and nitrogen levels. Agricultural Water Management, 98: 1607-14.

Roy, N., Laskar, S. and Barik, A. (2013). Amino acids through developmental stages of sunflower leaves.Acta Bot Croat, 72 (1): 23-33.

Ruso, V. M. (2006). Mineral nutrient and protein contents in tissues and yield of navy bean, in response to nitrogen fertilization and row spacing. Journal of Food Agiculture and Environment, 4(2): 168-71.

Russel, J. R., Irlbeck, N. A., Hallauer, A. R., Buxton, D. R. (1992). Nutritive value and ensiling characteristics of maize herbage as influenced by agronomic factors. Animal Feed Science Technology, 38: 11-24.

Sawan, Z. M. (2006). Egyptian cotton (GossypiumbarbadenseL.) yield as affected by nitrogen fertilization and foliar application of potassium and mepiquat chloride. Commun Bio Crop Science, 1(2): 99 -105 .

Shahin, M. G., Abdrabou, R. Th., Abdelmoemn, W. R. and Hamada, M. M. (2013). Response of growth and forage yield of pearl millet (Pennisetumgalucum) to nitrogen fertilizer rates and cutting height. Annals of Agricultural Sciences, 58(2): 153-62.

Sharma, A. K., Sharma, A. K., Sharma, R. K., Rajiv, B. and Rai, P. K. (2012). Effect of different levels of nitrogen, organic manure and planting time on yield and quality of hybrid napier. Indian Journal of Animal Nutrition, 29 (1): 33-39.

Sharma, P. K., Kalra, V. K. and Tiwana, U. S. (2016). Effect of farmyard manure and nitrogen levels on growth, quality and fodder yield of summer maize (Zea mays L.). Agricultural Research Journal, 53(3): 355-59.

Singh, P. and Sumeriya, H. K. (2012). Effect of nitrogen on yield, economics and quality of fodder sorghum genotypes. Annals of Plant and Soil Research, 14(2):133-5.

Somashekar, K. S., Shekara, B. G., Kalyana, Murthy, K. N. and Harish, L. (2014). Yield, nitrogen uptake, available soil nutrients and economics of multicut fodder sorghum (Sorghum sudanense L.) to different seed rates and nitrogen levels. Forage Research, 40(1): 23-27.

Tajul, M. I., Alam, M. M., Hossain, S. M. M., Naher, K., Rafii, M. Y. and Latif, M. A. (2013). Influence of Plant Population and Nitrogen-Fertilizer at Various Levels on Growth and Growth Efficiency of Maize. Scientific World Journal, 1-9.

Taute, A., Van Niekerk, W. A., Rethman, N. F. G. and Coertze, R. J. (2002). An evaluation of nitrogen fertilisedPanicum maximum cv. Gatton at different stages of 
maturity during autumn: 1 . Dry matter yield and certain qualitative parameters. South African Journal of Animal Sciences, 32(3): 208-15.

Tena, W. and Beyene, S. (2011). Identification of growth limiting nutrient(s) in alfisols: Soil physico-chemical properties, nutrient concentrations and biomass yield of maize. American Journal of Plant Nutrition Fertilizer Technology, 1: 23-35

Thavaprakaash, N., Velayudham, K. and Muthukumar. (2008). Response of crop geometry, intercropping systems and INM practices on yield and fodder quality of baby corn. Asian Journal of Scientific Research, 1(2): 153-59.

Tilley, J. M. A. and Terry, R. A. (1963). A two stage technique for the in vitro digestion of force crops. British Journal of Grassland Society, 18:104-11.

Tiwana, M. S., Puri, K. P., Tiwana, U. S. and Singh, A. (2004). Forage production potential of napier-bajra hybrid varieties under different nitrogen levels. Forage Research, 30: 80-85.

Uddin, M. M., Khandaker, Z. H., Sultana, M. N. (2005). Effect of levels of nitrogen with or without phosphorus fertilizer on oat (Avena sativa) forage production harvested at various ages: II. Nutritive value and macro mineral contents. Bangladesh Journal of Animal Sciences, 34 (1-2): 73-81.

Vuckovic, S., Simic, A., Dordivic, N., Zivanovic, T., Stojanovic, I. and Stanisavljevic, R. (2005). Effect of nitrogen fertilizer and underseeding on the productivity and chemical composition of Cynosuretumcristatitype meadows on hilly-mountains grassland in Serbia. Grassland Science in Europe, 10: 489-92.

Xiangfeng, Z., Shikui, D., Xujiang, Y. and Zizhi, H. (2007). Variation of productivity and nutritive values of oat (Avena sativa) with geographical locations in Gansu Province of Northwest China under irrigation and fertilization conditions. African Journal of Biotechnolgy, 6 (5):553-60

Zahid, M. S., Haqqani, M. S., Mufti, M. S. and Shafeeq, M. S. (2002). Optimization of $\mathrm{N}$ and $\mathrm{P}$ fertilizer for higher fodder yield and quality in mottgrass under irrigationcum rainfed conditions of Pakistan. Asian Journal of Plant Sciences, 1(6):690-3

Zhai, G., Shen, Y., Zhai, Y., Liu, X. and Jiang, H. (2008). Forage yield performance and nutritive value of selected wild soybean ecotypes. Canadian Journal of Plant Sciences, 88: 465-72. 